\title{
IMPLEMENTASI KONSEP CRM PADA PEMASARAN ASESORIS KOMPUTER DI CV.STICOM BERBASIS ANDROID
}

\author{
Yati Nurhayati ${ }^{1}$, Ade Rosidin ${ }^{2}$ \\ Fakultas Ilmu Komputer Universitas Kuningan \\ Jalan Tjut Nyak Dhien No. 36 A Cijoho Kuningan Jawa Barat 45513Telepon (0232) 2875097 \\ yati.nurhayati@uniku.ac.id ${ }^{1}$, rosidinade4@gmail.com ${ }^{2}$
}

CV. STICOM merupakan perusahaan yang bergerak penjualan perangkat komputer,asesoris komputer dan dibidang jasa pelayanan perbaikan,. Dalam proses proses pemasaran masih dilakukan secara manual bertatap muka. maka dari itu perlu adanya sebuah sistem untuk mengefektifkan dan mengefisienkan itu semua. Adapun sistem yang dibangun untuk frontend mencakup proses informasi asesoris komputer, pembelian asesoris komputer, notifikasi promo, diskon dan konsultasi keluhan, Sedangkan sistem untuk backend mencakup pengelolaan transaksi pembelian, data customer, pengelolaan info promo dan diskon, pengelolaan data keluhan dan laporan penjualan perbulan. Dalam pembangunan sistem penulis menggunakan metode RUP (Rational Unified Process) sebagai metode pengembangan sistem. Sistem layanan perbaikan yang dibuat menggunaka dua platform untuk frontend menggunakan android, untuk backend menggunakan PHP dan database menggunakan MySQL. Dari sistem yang dibangun dapat memberikan solusi untuk proses pemasaran asesoris komputer sudah terkomputerisasi dan media komunikasi antara konsumen dan perusahaan menjadi lebih efektif dan efisien.

Kata Kunci : Android, Implementasi CRM, Pemasaran, PHP

$C V$. STICOM is a company engaged in the sale of computer equipment, computer accessories and repair services,. In the process of marketing process is still done manually face to face. therefore there is a need for a system to streamline and streamline it all. The system that is built for the frontend includes the process of computer accessories information, the purchase of computer accessories, promo notifications, discounts and consultation complaints, While the backend system includes the management of purchase transactions, customer data, management of promo and discount info, data management complaints and monthly sales reports. In system development the author uses RUP (Rational Unified Process) method as a system development method. The repair service system made using two platforms for frontend using android, for backend using PHP and database using MySQL. From the built system can provide solutions for the process of marketing computer accessories have been computerized and communication media between consumers and companies become more effective and efficient.

Keywords: Android, CRM Implementation, Marketing, PHP

\section{PENDAHULUAN}

\subsection{Latar Belakang Masalah}

Persaingan usaha yang ketat ini mengharuskan perusahaan untuk berfokus kepada kebutuhan yang diinginkan oleh konsumen. Perusahaan mulai mengubah pola pikir dari orientasi keuntungan ke arah faktorfaktor potensial lainnya seperti kepentingan Customer dan tingkat kepuasan Customer menjadi faktor utama yang harus diperhatikan oleh perusahaan Kondisi persaingan bisnis yang terjadi pada saat sekarang ini membuat perusahaan harus menyadari dengan cermat target pasar yang dituju. Beberapa riset yang telah dilakukan menunjukkan bahwa dalam strategi bisnis mempertahankan Customer lama lebih menguntungkan daripada menarik 
Customer baru. (Ovi Diantina, Mira Afrina, Ali ibrahim jurnal Volume 4 No 02 oktober 2012)

Tidak semua perusahaan atau pelaku bisnis menawarkan suatu produk yang mereka jual menyadari akan pentingnya suatu pelayanan terhadap Customer. Hal ini bisa terjadi akibat banyaknya aspek kepuasan Customer, atau produk yang dijual merupakan produk unggulan atau banyak diminati oleh para Customer, sehingga perusahaan tidak memiliki kecemasan atau kekhawatiran akan ditinggalkan oleh Customer. CRM (Customer Relationship Management) merupakan suatu jenis manajemen yang secara khusus membahas teori mengenai penanganan hubungan antara perusahaan dengan Customernya dengan tujuan meningkatkan nilai perusahaan di mata para Customernya.

CV.STICOM merupakan salah satu perusahaan yang bergerak dibidang penjualan asesoris komputer, dimana pemasaran produk di CV.STICOM dilakukan secara face to face (transaksi langsung di lokasi penjualan) sehingga target pemasaran menjadi terbatas, pencatatan transaksi secara semi manual (menggunakan microsoft excel) sehingga mudah terjadi human error, sulitnya melakukan pencarian data, update harus dilakukan satu persatu, kemudian untuk pembuatan laporan karyawan harus mencocokan data dari nota penjualan, pembelian, dan data stok barang sehingga kurang efisien. Sulitnya CV.STICOM dalam memberikan informasi mengenai promo, diskon, karena belum adanya aplikasi yang menghubugkan antara CV.STICOM dengan Customer secara terkomputerisasi.

Dengan seiringnya perkembangan teknologi akhir-akhir ini cendrung mengarah pada teknologi mobile, salah satunya seperti android yang saat ini merupakan sistem operasi yang sangat populer yang banyak digunakan di perangkat mobile. Android merupakan sistem oprasi perangkat mobile berbasis linux, kelebihannya dari sistem oprasi lain yaitu android bersifat open source sehingga pengguna dapat mengembangkan fitur yang belum ada sesuai dengan keinginan. Ketertarikan Customer terhadap android sangat tinggi, hal ini dapat dilihat dari banyaknya transaksi penjualan smart phone di CV.STICOM.

\subsection{Identifikasi Masalah}

Berdasarkan latar belakang di atas, maka permasalahan yang akan dibahas dalam penelitian adalah sebagai berikut:

1. Lambatnya aktifitas pemasaran dalam meningkatkan proses penjualan Asesoris computer

2. Terbatasnya target pasar perusahaan karna proses pemasaran masih dilakukan secara face to face

3. Sulitnya perusahaan dalam memberikan informasi mengenai,promo produk, dan diskon

4. Belum adanya aplikasi khusus untuk melayani customer dalam proses pemesanan asesoris komputer di CV.STICOM.

\section{METODELOGI PENELITIAN}

\subsection{Implementasi}

Menurut Kadir, A dalam bukunya "Perancangan Sistem Informasi" Andi , Yogyakarta, 2003. "Implementasi adalah kegiatan yang dilakukan untuk menguji data dan menerapkan sistem yang diperoleh dari kegiatan seleksi". Implementasi merupakan salah satu unsur pertahapan dari keseluruhan pembangunan sistem komputerisasi, dan unsur yang harus dipertimbangkan dalam pembangunan sistem 
komputerisasi yaitu masalah perangkat lunak (software), karena perangkat lunak yang digunakan haruslah sesuai dengan masalah yang akan diselesaikan, disamping masalah perangkat keras (hardware) itu sendiri.

\subsection{Customer Relationship Management (CRM)}

Menurut Komaruddin Sastradipoeral (2003:60), menyatakan bahwa: Customer adalah setiap pembeli yang mengadakan transaksi di pasar dengan penjual. Pelanggan dalam garis besarnya dapat dibedakan ke dalam pelanggan individual dan pelanggan bisnis. Pelanggan individual (individual customers) adalah seseorang yang mengadakan transaksi pembelian di pasar dengan penjual. Sedangkan pelanggan bisnis (business customers) adalah organisasi-organisasi yang membeli barang atau jasa untuk digunakan, baik langsung atau tidak langsung untuk pelaksanaan usahanya sendiri.

\subsection{Pemasaran}

Menurut Kotler (2000:3), "Pemasaran (marketing) merupakan hal yang sangat mendasar sehingga tidak dapat dilakukan sebagai fungsi yang terpisah". Pemasaran sebenarnya lebih dari sekedar mendistribusikan barang dari produsen ke konsumen. Proses pemasaran telah terjadi dan dimulai jauh sebelum barang-barang diproduksi. Berikut 3 unsur penting konsep pemasaran diantaranya yaitu :

1. Orientasi pada konsumen Pada konsep pemasaran sebagai bagian dari manajemen pemasaran adalah hal yang menjadi prioritas utama saat menghasilkan sebuah produk bisnis. Pada dasarnya usaha bisnis yang dilakukan adalah upaya pemenuhan terhadap kebutuhan konsumen. Konsumen adalah orientasi utama yang harus dipertimbangkan dalam segala hal dan macam bentuk strategi bisnis.

2. Penyusunan kegiatan-kegiatan pemasaran secara integral atau menyeluruh

Manajemen pemasaran dapat melalui konsep pemasaran sebagai bagian dari falsafah bisnis yang dapat dijalankan menghendaki adanya pengaturan secara yang dinamis berbagai bentuk penyusunan kegiatan pemasaran secara yang lebih menyeluruh.

3. Kepuasankonsumen

Kepuasan konsumen juga adalah salah satu unsur penting yang sangat perlu diperhatikan dalam penyusunan konsep pemasaran. Manajemen pemasaran yang baik akan menghendaki adanya hasil kepuasan konsumen yang maksimal sebagai akibat dari proses marketing yang berjalan baik. Kepuasan konsumen tidak hanya diukur dari bagaimana kualitas produk yang dihasilkan, namun juga di ukur dari bagaimana cara dan strategi pemasaran itu dijalankan.

\subsection{UML (Unified Modelling \\ Language)}

UML (Unified Modelling

Language) adalah salah satu alat bantu yang sangat handal di dunia pengembangan sistem yang berorientasi objek. Hal ini disebabkan UML menyediakan bahasa pemodelan visual yang memungkinkan bagi pengembang sistem untuk membuat cetak biru atas visi mereka dalam bentuk yang baku, mudah dimengerti serta dilengkapi dengan mekanisme yang efektif untuk berbagi (sharing) dan mengkomunikasikan rancangan mereka dengan yang lain (Salahudin M, Rosa A.S. 2011). 
UML merupakan kesatuan dari bahasa pemodelan yang dikembangkan oleh Booch, Object Modeling Technique (OMT) dan Object Oriented Software. Engineering (OOSE). Metode Booch dari Grady Booch sangat terkenal dengan nama metode Design Object Oriented. Metode ini menjadikan proses analisis dan design ke dalam empat tahapan iterative, yaitu: identifikasi kelas-kelas dan obyek obyek, identifikasi semantic dari hubungan obyek dan kelas tersebut, perincian interface dan implementasi. Keunggulan metode Booch adalah pada detil dan kayanya dengan notasi dan elemen. Pemodelan OMT yang dikembangkan oleh

Rumbaugh didasarkan pada analisis terstruktur pemodelan entityrelationship. Tahapan utama dalam metodologi ini adalah analisis, design sistem, design obyek dan implementasi. Keunggulan metode ini adalah dalam penotasian yang mendukung semua konsep OO. Metode OOSE dari Jacobson lebih member penekanan pada use case. OOSE memiliki tiga tahapan yaitu membuat model requirement dan analisis, design dan implementasi, dan model pengujian (test model). Keunggulan metode ini adalah mudah dipelajari karena memiliki notasi yang sederhana namun mencakup seluruh tahapan dalam rekayasa perangkat lunak.

Design UML, metode Booch, OMT dan OOSE digabungkan dengan membuang elemen-elemen yang tidak praktis ditambah dengan elemenelemen dari metode lain yang lebih efektif dan elemen-elemen baru yang belum ada pada metode terdahulu sehingga UML lebih ekspresif dan seragam dari pada metode lainnya.

\section{HASIL DAN PEMBAHASAN} 3.1 Analisis yang Sedang Berjalan
Analisis sistem yang sedang berjalan ini di deskripsikan dengan menggunakan flowmap. Dimana flowmap merupakan gambaran yang menerangkan bagaimana alur data berpindah dari satu bagian ke bagian lain yang akan dijelaskan pada gambar berikut ini:

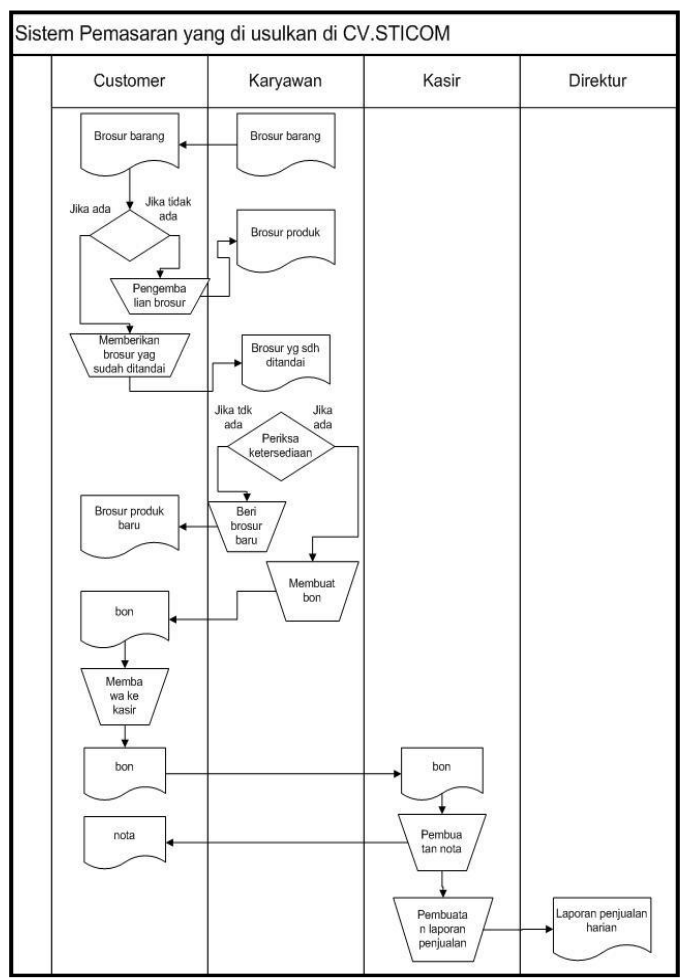

Gambar 1. Sistem yang sedang berjalan

\subsection{Sistem yang Diusulkan}

Analisis sistem yang diusulkan dalam implementasi konsep CRM pada pemasaran asesoris komputer ini dapat dilihat pada proses yang digambarkan dibwah ini : 
JURNAL NUANSA INFORMATIKA

Volume 12 Nomor 2, Juli 2018

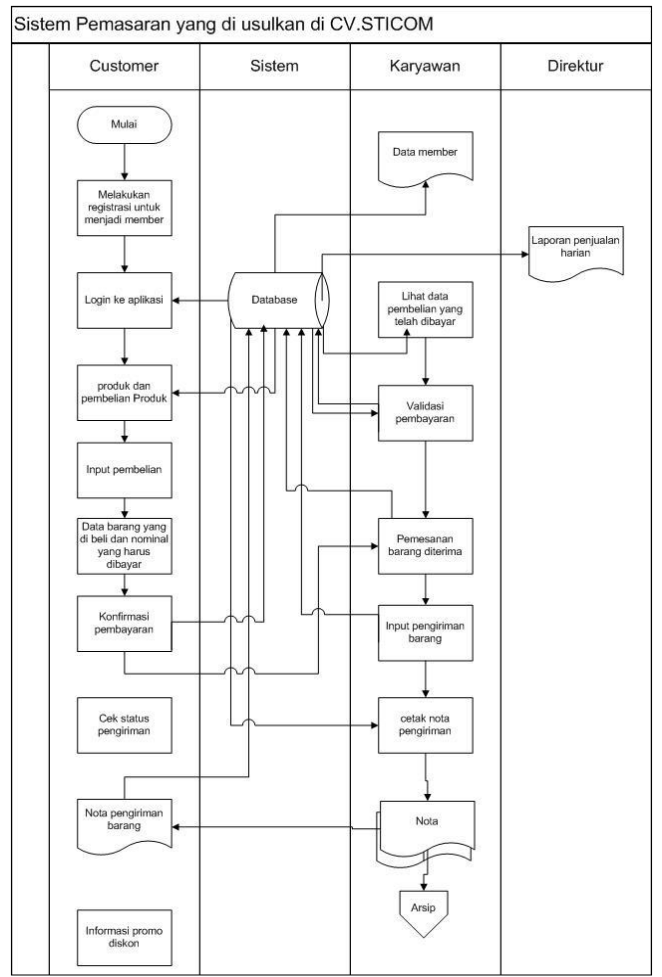

Gambar 2. Sistem yang diusulkan

\subsection{Perancangan Sistem}

1. Use Case Diagram

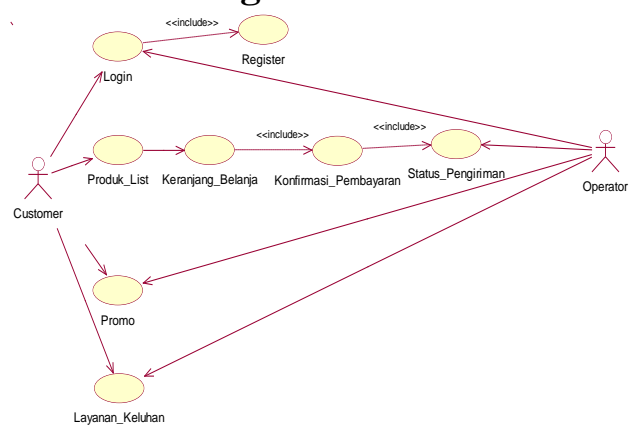

Gambar 3. Use Case Diagram

\section{Activity Diagram}

1) Activity Diagram Register

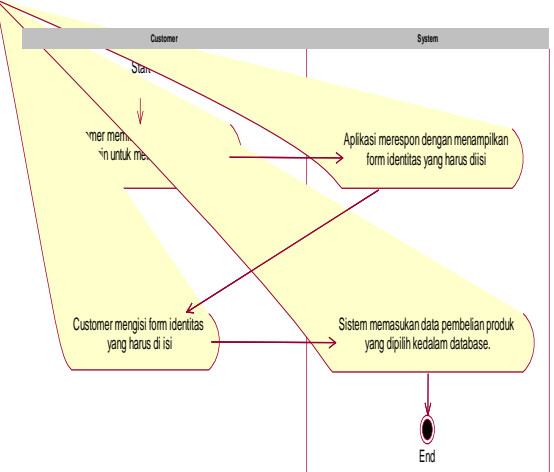

Gambar 4. Activity Diagram Register
3. Class Diagram

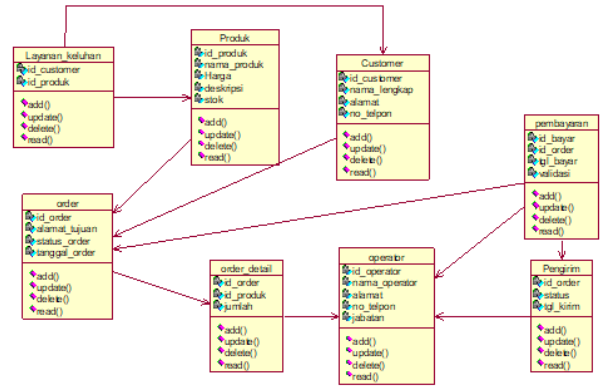

Gambar 5. Class Diagram

4. Sequence Diagram

1) Sequence Diagram Register

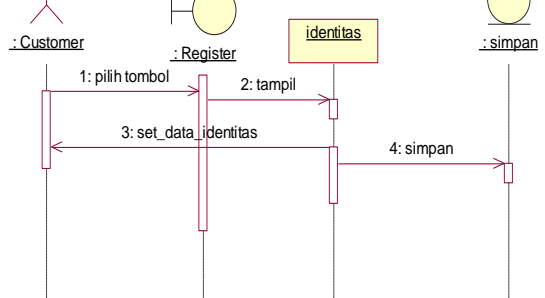

Gambar 6. Sequence Diagram Register

\subsection{Tab Daftar}

Tampilan tab daftar saat membuka pendaftaran akun

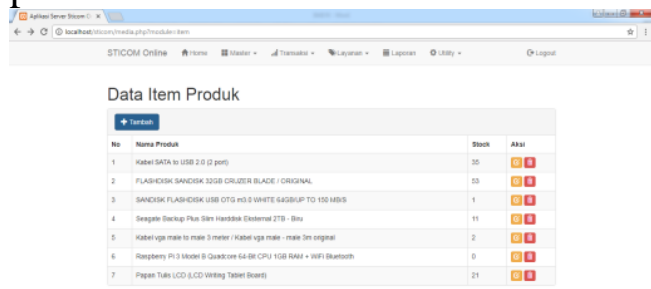

Gambar 7. Halaman Kelola Produk

Pemasaran Asesoris Komputer

3.5 Halaman kelola ongkos kirim

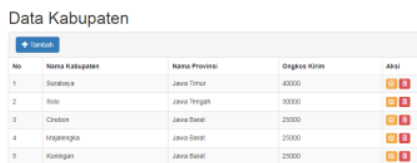

Gambar 8. Halaman kelola ongkos kirim

\subsection{Halaman Kelola Data Promosi}




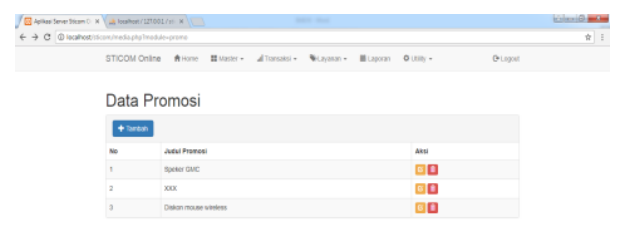

Gambar 9. Halaman Kelola Data

Promosi

\subsection{Halaman Transaksi Pemasaran}

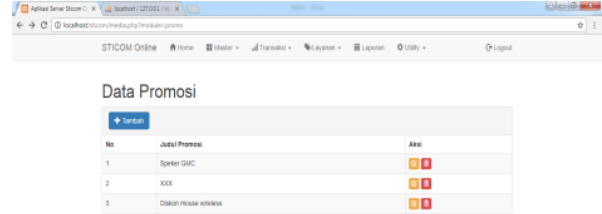

Gambar 10. Halaman Transaksi

Pemasaran

\subsection{Halaman \\ Konfirmasi \\ Pembayaran}

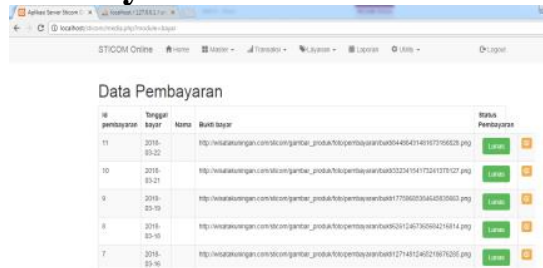

Gambar 11. Halaman Konfirmasi

Pembayaran

\subsection{Halaman Konsultasi}

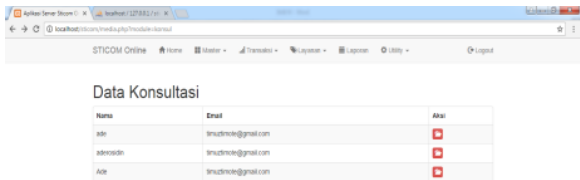

Gambar 12. Halaman Konsultasi

\subsection{Halaman Laporan}

p-ISSN : 1858-3911, e-ISSN : 2614-5405

https://journal.uniku.ac.id/index.php/ilkom

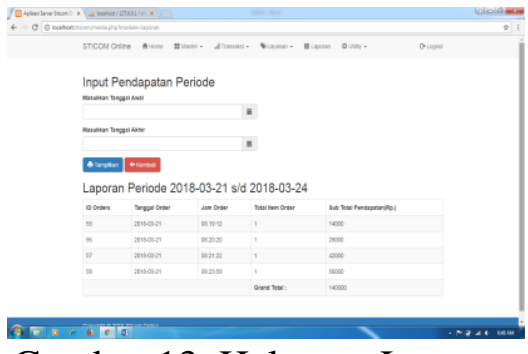

Gambar 13. Halaman Laporan

3.11Halaman Beranda

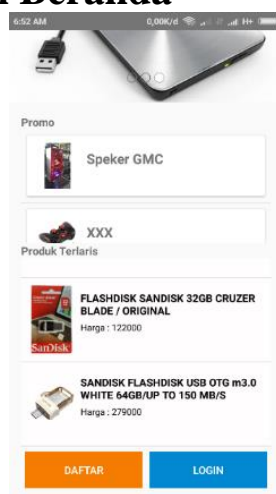

Gambar 14. Halaman Beranda

Keterangan:

Ketika aplikasi pertama dijalankan akan muncul tampilan beranda yang menampilkan promo dan produk terlaris.

\subsection{Halaman Pendaftaran Member}

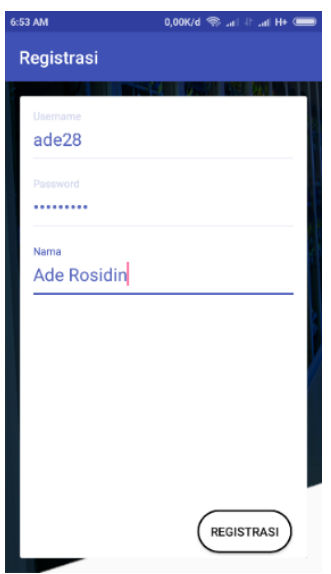

Gambar 15. Halaman Pendaftaran Member

Keterangan:

1. Username berfungsi untuk memasukan user name peengguna yang akan didaftarkan. 
2. Password berfungsi untuk memasukan password member yang akan digunakan.

3. Nama berfungsi untuk memasukan nama member yang akan didaftarkan.

\subsection{Halaman Login}

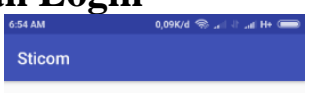

Keterangan:

Gambar 16. Halaman Login

1. Username berfungsi untuk memasukan user name pengguna yang akan didaftarkan.

2. Password berfungsi untuk memasukan password member yang akan digunakan.

\subsection{Halaman Menu Utama}

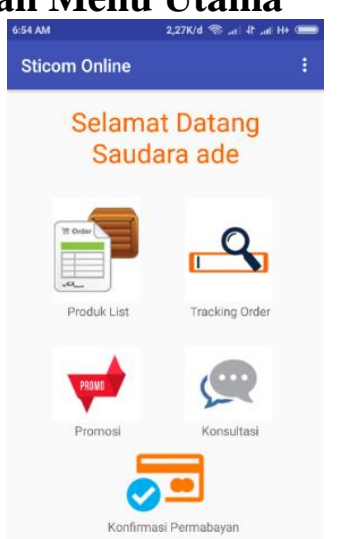

Gambar 17. Halaman Menu Utama Keterangan:

1. Produk list berfungsi untuk melihat informasi dan membeli produk asesoris yang ditawarkan

2. Tracking order berfungsi untuk melihat history order dan melihat posisi barang yang sudah di order.
3. Promosi berfungsi untuk melihat informasi promo.

4. Konsultasi berfungsi untuk melakukan konsultasi dengan penjual apabila ada ketidak puasan dengan produk yang dibeli.

5. Konfirmasi pembayaran berfungsi untuk mengunggah fhoto bukti transfer apabila sudah melakukan pembelian produk asesoris.

\subsection{Halaman Produk List}

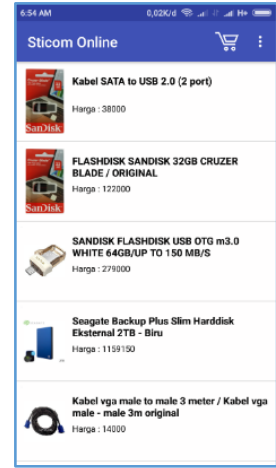

Gambar 18. Halaman Produk List Keterangan:

Ketika memilih produk list akan menampilkan informasi produk yang ditawarkan dan bisa membelinya ketika produk itu ingin dibeli.

\subsection{Halaman Keranjang Belanja

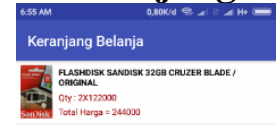

Gambar 19. Halaman Keranjang Belanja

Keterangan:

merupakan halaman untuk melihat total pembayaran dan jumlah barang yang sudah dibeli.

\subsection{Halaman Data Penerima}




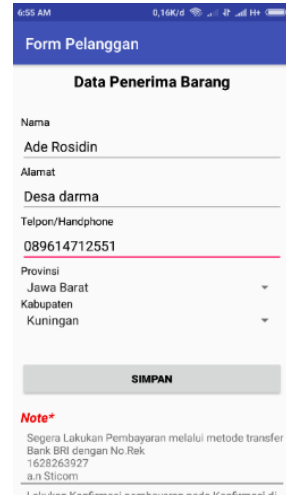

Gambar 20. Halaman data Penerima

Keterangan:

merupakan halaman untuk mengisi data orang yang akan menerima produk yang sudah dibeli.

\subsection{Halaman Tracking Order}

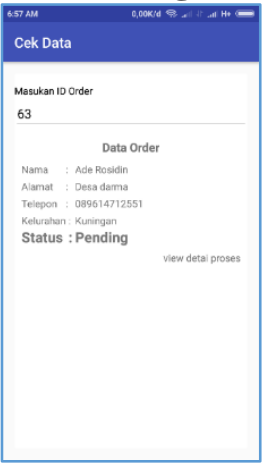

Gambar 21. Halaman Tracking Order

Keterangan:

merupakan halaman untuk melihat history dan status pengiriman produk

\subsection{Halaman Promo}

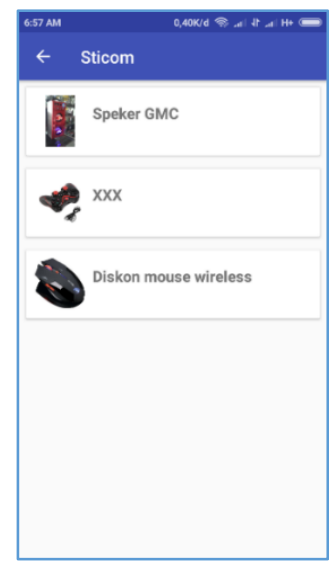

Gambar 22. Halaman Promo

Keterangan: merupakan halaman untuk melihat promo dari produk asesoris computer yang ditawarkan

\subsection{Halaman Konsultasi}

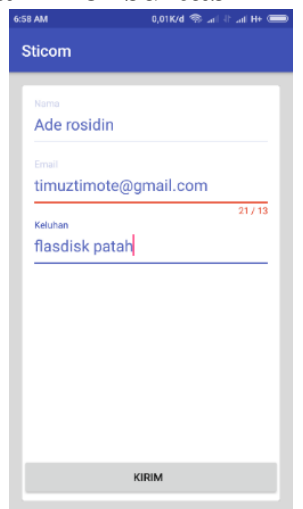

Gambar 23. Halaman Konsultasi Keterangan:

1. Username berfungsi untuk memasukan user name pengguna yang sudah terdaftar.

2. Email berfungsi untuk memasukan email yang digunakan oleh member.

3. Keluhan berfungsi untuk menuliskan keluhan yang akan kita sampaikan kepada penjual.

\section{KESIMPULAN}

Berdasarkan hasil analisa dan perancangan pada Implementasi konsep CRM pada pemasaran asesoris computer di |CV.STICOM berbasis android, maka diperoleh kesimpulan sebagai berikut :

1. Dengan adanya aplikasi pemasaran ini dapat mempermudah dalam menyampaikan informasi produk asesoris komputer sehingga bisa lebih optimal dalam penyampaian informasi kepada customer.

2. Pada aplikasi pemasaran asesoris komputer ini terdapat fasilitas berupa notifikasi sebagai media untuk menyampaikan informasi promo produk asesoris terbaru.

3. Dilengkapi dengan layanan diskon potongan harga berkala pertiga kali pembelian barang 
4. Adanya layanan keluhan untuk berkonsultasi dengan penjual apabila ada produk yang kurang dimengerti

5. Dengan terbangunnya aplikasi pemasaran asesoris komputer di CV. STICOM customer menyambut baik dan merasa terbantu dengan informasi yang disampaikan.

5. SARAN

Setelah penulis mengadakan penelitian, maka ada beberapa saran yang ingin penulis kemukakan agar aplikasi berjalan maksimal, antara lain:

1. Untuk mengoperasikan program aplikasi ini, diperlukan adanya pelatihan terlebih dahulu terhadap Admin.

2. Perlu adanya pengembangan dari sistem yang telah dibuat agar lebih baik dari segi tampilan maupun layanan pemasaran.

3. Masih terdapat kekurangan, sehingga penulis memiliki beberapa saran untuk mengembangkan aplikasi ini, diantaranya yaitu :

a. Aplikasi ini belum memiliki layanan poin member dan vocher.

b. Aplikasi ini belum memiliki fasilitas untuk forgot password user dari sisi client.

\section{DAFTAR PUSTAKA}

D. Kurniawan, 2009 "PenerapanAplikasi CRM

(Customer Relationship

Management) Berbasis Web Dalam

Bidang Jasa "

Ovi Diantina, Mira Afrina, Ali ibrahim

"Penerapan Customer Relationship

Management (CRM) Berbasis Web (Studi Kasus Pada Sistem Informasi Pemasaran di Toko YEN-YEN)",

Volume 4 No 02 oktober 2012

Anatasha Onna Carissa, Achmad fauzi, Srikandi Kumadji "Penerapan CRM (Customer Relationship Management) sebagai upaya untuk meningkatkan loyalitas pelanggan" Volume 15 No 01 oktober 2014

Teti Wijayanti, Imam Azhari "Pengembangan Customer Relationship Management berbasis web pada Griya Muslim Flora" Volume 01 No 01 Februari 2011

Kalakota, R. dan Robinson M 2001 " $E$ Business 2.0 Roadmap for Success, Massachusetts" : Addsion Wesley Longman Inc.

Zainal A. Hasibuan, PHD 2007 "Metodologi Penelitian Pada Bidang Ilmu Komputer Dan Teknologi Informasi"

Irwanto, S.kom.MM, Djon 2006 "Perancangan Object Oriented Software dengan UML" Andi Offset, Yogyakarta

Rosa A.S, M. Shalahuddin 2011 "Modul Pembelajaran Rekayasa Perangkat Lunak (Terstruktur dan Berorientasi Objek) " Bandung: Modula.

Safaat, Nazruddin. 2013. "Aplikasi Berbasis Android". Bandung : Informatika.

Tata Sutabri. 2012. "Konsep Sistem Informasi”. Yogyakarta: Andi. Tim Litbang MADCOMS. 2004. "Aplikasi Program PHP \& MySQL untuk Membuat Website Interaktif". Yogyakarta \& Madiun: Andi \& MADCOMS. 